\title{
Cytology and Distribution of Secretory Cell Types in the Mouse Hypophysis as Demonstrated with Immunocytochemistry ${ }^{1}$
}

\author{
BURTON L. BAKER AND DOUGLAS S. GROSS \\ The Reproductive Endocrinology Program, Department of Anatomy, Medical School, \\ The University of Michigan, Ann Arbor, Michigan 48109; and The Department of \\ Anatomy, School of Medicine, Temple University, Philadelphia, \\ Pennsylvania 19140
}

\begin{abstract}
Since differential chemical staining has been unsatisfactory for demonstration of specific secretory cell types in the hypophyseal pars distalis of the mouse, the objective of this study was to determine whether the peroxidase-antiperoxidase immunocytochemical procedure might be more effective. Accordingly, representative sections from the hypophyses of 17 female and 15 male adult mice of the Swiss-Webster strain were immunostained, 16 antisera to 5 pituitary hormones or their subunits being utilized. Five secretory cell types were demonstrated. Somatotropes were ovoid to spheroidal and distributed quite generally in the gland except for the "sex zone" where they were scarce. Somatotropes were larger and more numerous in the male than in the female. Mammotropes were polyhedral and also generally distributed in the gland except for the "sex zone" where few were observed. Mammotropes were larger and more numerous in the female than in the male. Corticotropes were small, stellate and few. They were most common near the ventral surface of the gland and formed bilateral centromedial groups in the lateral wings. Thyrotropes were usually large and polyhedral. They were restricted almost solely to the ventral region of the pars distalis. Gonadotropes were polyhedral, and generally distributed, except for aggregation in the cephalomedian "sex zone." Most gonadotropes appeared to contain both luteinizing hormone and follicle-stimulating hormone. Thus, all secretory cell types recognized in other species can be demonstrated readily in the mouse hypophysis with immu. nocytochemistry.
\end{abstract}

Fewer cytological studies of the hypophy. seal pars distalis have been carried out in the mouse than in some other mammals. A major reason for this neglect is the difficulty usually experienced in obtaining a satisfactory delineation of cell types with differential chemical staining. ${ }^{2}$ Dev and Srivastava ('75) summarized the frustrations of many investigators in this regard. As a result, some cell types, e.g., the corticotrope and mammotrope, have not been identified conclusively, and the distributions of these and other cell types in the gland are poorly understood. With the advent of immunocytochemistry, a means became available for (a) advancing our understanding of these aspects of pituitary cytology, and (b) procurement of additional evidence concerning the functions previously ascribed to cell types identified by ultrastructural or tinctorial criteria. Only two attempts have been made to utilize immunohistological ${ }^{2}$ methods for investigation of the mouse hypophysis. Weidner (72) was able to demonstrate somatotropes with immunofluorescence using antiserum to bovine somatotropin but failed to reveal mammotropes with antiserum to bovine mammotropin. Also, in a study of mouse thyrotropic tumors Furth et al. ('73) used immunocytochemistry to demon.

\footnotetext{
Accepted March 27, '78.

1 Supported in part by a research grant from the National Institute for Child Health and Human Development, HD-03159. We thank Ya-Yen Yu, Frances Wicks and Carol Black for their technical assistance.

2 "Differential chemical staining" refers to classical methods that involve the direet or indirect attachment of dyes to cellular components. The term "immunohistological" encompasses both immunofluorescence and immunocytochemical procedures.
} 
TABLE 1

Antisera used for demonstration of cell types

\begin{tabular}{|c|c|c|c|c|}
\hline Cell type & Antiserum & Dilution & Origin & $\begin{array}{l}\text { Staining } \\
\text { intensity }\end{array}$ \\
\hline $\begin{array}{l}\text { Somatotrope } \\
\text { Mammotrope }\end{array}$ & $\begin{array}{l}\text { Anti-hGH, B85 } \\
\text { Anti-rPrl } \\
\text { Anti-rPrl, 625 } \\
\text { Anti-hPrl } \\
\text { Anti-oPrl, B107 }\end{array}$ & $\begin{array}{l}1 / 200 \\
1 / 400 \\
1 / 400 \\
1 / 25 \\
1 / 50\end{array}$ & $\begin{array}{l}\text { B. L. B. } \\
\text { A. F. Parlow } \\
\text { A. R. Midgley } \\
\text { Calbiochem } \\
\text { B. L. B. }\end{array}$ & $\begin{array}{c}+t+ \\
++t \\
++t \\
0 \\
0\end{array}$ \\
\hline Corticotrope & $\begin{array}{l}\text { Anti- } \beta^{1-24} \text { - } \\
\text { corticotropin, B44 } \\
\text { Anti-p } \beta^{17-39} \\
\text { corticotropin, B37 }\end{array}$ & $\begin{array}{l}1 / 100 \\
1 / 25\end{array}$ & $\begin{array}{l}\text { B. L. B. } \\
\text { B. L. B. }\end{array}$ & $\begin{array}{l}+t+ \\
+t+\end{array}$ \\
\hline Thyrotrope & $\begin{array}{l}\text { Anti-hTSH } \beta \\
\text { Anti-bTSH } \beta \\
\text { Anti-hTSH } \\
\text { Anti-bTSH }\end{array}$ & $\begin{array}{l}1 / 1,000 \\
1 / 1,000 \\
1 / 1,000 \\
1 / 100\end{array}$ & $\begin{array}{l}\text { J.G. Pierce } \\
\text { J.G. Pierce } \\
\text { W. D. Odell } \\
\text { J. G. Pierce }\end{array}$ & $\begin{array}{l}++t \\
++t \\
++ \\
+t+\end{array}$ \\
\hline LH-Gonadotrope & $\begin{array}{l}\text { Anti-hCG, } 391 \\
\text { Anti-bLH } \beta \\
\text { Anti-hLH } \beta \\
\text { Anti-rLH } \beta\end{array}$ & $\begin{array}{l}1 / 1,000 \\
1 / 3,000 \\
1 / 500 \\
1 / 50\end{array}$ & $\begin{array}{l}\text { A. R. Midgley } \\
\text { J. G. Pierce } \\
\text { NIAMDD } \\
\text { A. F. Parlow }\end{array}$ & $\begin{array}{l}+++ \\
+++ \\
++ \\
++\end{array}$ \\
\hline FSH-Gonadotrope & Anti-hFSH $\beta$ & $1 / 100$ & A. F. Parlow & ++ \\
\hline
\end{tabular}

strate several cell types in hypophyses of the normal mouse.

The purpose of this report is to describe the morphology and distribution of secretory cell types in the hypophyseal pars distalis of the adult mouse as revealed by immunocytochemistry, with special emphasis being placed on differences observed between the sexes. We hope that this description will demonstrate the usefulness of immunocytochemistry for cytophysiologic investigation of the mouse pituitary gland and will be a source of basic information for future studies.

\section{MATERIALS AND METHODS}

Observations were made on hypophyses of 17 female and 15 adult male mice of the SwissWebster strain. The mice were housed in airconditioned quarters illuminated on a 14hour-light/10-hour-dark schedule, the lights being turned on at 5:00 A.M. and off at 7:00 P.M. They received water and food ad libitum.

The mice were killed by decapitation. After removal of the superior part of the cranium and the brain, the base of the cranium with the hypophysis in situ was immersed in the fixative, Bouin's fluid, for approximately two hours. After the gland had hardened sufficiently to minimize subsequent mechanical damage, the hypophysis was excised and immersed in Bouin's fluid for a total fixation time of 24 hours. Subsequently, the glands were embedded in Paraplast and sectioned serially at 3-5 $\mu \mathrm{m}$. Most glands were cut trans- versely while others were sectioned horizontally. Regularly spaced trial sections were mounted and stained with the hematoxylinaldehyde fuchsin-Masson procedure to facilitate selection of sections for immunostaining. For each hormonal antiserum used, sections representing three equally spaced levels in the gland were immunostained; thus, for those cut transversely, such sections represented the rostral, middle, and caudal regions of the gland.

The peroxidase-antiperoxidase (PAP) method of Sternberger ('74) was used for immunostaining. Modifications in the procedure adopted in this laboratory have been summarized (Baker et al., '77). 3,3'-Diaminobenzidine (DAB) served as the label. The primary hormonal antisera ${ }^{3}$ were used at varied dilutions (table 1) which were high enough to minimize background staining due to contaminating antibodies while still giving maximal staining intensity. The first antiserum listed under each cell type (table 1) was utilized for routine staining of a cell type. Immunostain. ing of a cell type with several antisera showed whether a particular cell type could be demonstrated with antibodies to hormonal antigens that differed chemically or by species of ori-

\footnotetext{
"Abbreviations employed are the following: " $a$ " or "anti" as a prefix to the name of a hormone, or its abbreviation, indicates an antiserum to the hormone named; $r, p, h, o$, and b preceding the name or abbreviation for a hormone refers to the species of origin. i.e., rat, porcine, human, ovine, and bovine, respectively; TSH, thyrotropin; FSH, follicle-stimulating hormone; $\mathrm{LH}$, luteinizing hor mone; Prl, prolactin; CG, chorionic gonadotropin; C, corticotropin.
} 
TABLE 2

The influence of preabsorption of antisera with pituitary hormones on their utility for immunostaining cell types

\begin{tabular}{|c|c|c|c|c|c|c|c|c|c|c|c|}
\hline \multirow{2}{*}{$\begin{array}{l}\text { Antiserum/ } \\
\text { hormonal } \\
\text { absorbents }\end{array}$} & \multicolumn{5}{|c|}{$\begin{array}{c}\text { Final } \\
\text { concentration of } \\
\text { absorbent }(\mathrm{ng} / \mu \mathrm{l})\end{array}$} & \multirow{2}{*}{$\begin{array}{c}\text { Antiserum/ } \\
\text { hormonal } \\
\text { absorbents }\end{array}$} & \multicolumn{5}{|c|}{$\begin{array}{c}\text { Final } \\
\text { concentration of } \\
\text { absorbent }(n g / \mu l)\end{array}$} \\
\hline & 0.5 & 2.5 & 5 & so & 500 & & 0.5 & 2.5 & 5 & 50 & 500 \\
\hline Anti-hGH & & & & & & Anti-hFSH $\beta$ & & & & & \\
\hline hGH & + & + & 0 & & & hFSH $\beta$ & 0 & & & & \\
\hline rGH & & & & \pm & & hFSH & & \pm & 0 & & \\
\hline rPrl & & & & & + & rFSH & & & + & \pm & 0 \\
\hline$\beta^{2-24} \cdot C$ & & & & & +1 & hTSH & & & & \pm & 0 \\
\hline rTSH & & & & & +2 & $\mathrm{rTSH}$ & & & & & \pm \\
\hline rFSH & & & & & +1 & hCG & & & & & + \\
\hline $\mathrm{hCG}$ & & & & & + & $\beta^{1-24}-C$ & & & & & + \\
\hline & & & & & & rPrl & & & & & + \\
\hline Anti-rPrl & & & & & & $\mathrm{rGH}$ & & & & & + \\
\hline rPrl & + & \pm & $O$ & & & & & & & & \\
\hline rGH & & & & & + & Anti-hCG & & & & & \\
\hline$\beta^{1-24}-C$ & & & & & +1 & hCG & + & 0 & & & \\
\hline rTSH & & & & & +2 & rFSH & & & & + & \pm \\
\hline rFSH & & & & + & & rTSH & & & + & 0 & \\
\hline hCG & & & & & + & hTSH & & + & 0 & & \\
\hline & & & & & & $\mathrm{hTSH} \beta$ & & & + & 0 & \\
\hline Anti- $\beta^{1-24}-\mathrm{C}$ & & & & & & rGH & & & & & + \\
\hline$\beta^{1-24}-\mathrm{C}$ & 0 & & & & & rPrl & & & & & + \\
\hline rGH & & & & & + & $\beta^{1-24} \cdot C$ & & & & + & \pm \\
\hline rPrl & & & & & + & & & & & & \\
\hline rFSH & & & & + & & $A n t i-b L H \beta$ & & & & & \\
\hline rTSH & & & & + & & hCG & & & & + & \\
\hline $\mathrm{hCG}$ & & & & & + & bLH & + & + & 0 & & \\
\hline & & & & & & rFSH & & & + & + & \pm \\
\hline Anti-hTSH $\beta$ & & & & & & rTSH & & & + & \pm & 0 \\
\hline hTSH $\beta$ & & $\mathrm{O}$ & & & & $\mathrm{rGH}$ & & & & & + \\
\hline hTSH & & 0 & & & & rPrl & & & & & + \\
\hline rTSH & & & & + & \pm & $\beta^{1-24}-C$ & & & & & + \\
\hline rFSH & & & & & + & & & & & & \\
\hline hCG & & & & & + & & & & & & \\
\hline$\beta^{1-24} \cdot C$ & & & & & + & & & & & & \\
\hline rPrl & & & & & + & & & & & & \\
\hline $\mathrm{rGH}$ & & & & & + & & & & & & \\
\hline
\end{tabular}

For abbreviations see footnote 3 .

+ , Intense staining, i.e., no neutralization of the sntiserum; \pm reduced staining, i.e., partial neutralization; $O$ no staining, i.e., complete neu. tralization.

'Staining was still obtained at an absorbent concentration of $1 \mu \mathrm{g} / \mu \mathrm{l}$.

${ }^{2}$ Staining was atill obtained at an absorbent concentration of $750 \mathrm{ng} / \mu \mathrm{l}$.

gin, thus providing information concerning specificity of the technique.

In order to examine specificity of the antisera for localization of hormonal antigens, the antisera were preabsorbed with either the hormone ${ }^{4}$ used as the antigen, or with other pituitary hormones, and then used in the immunocytochemical procedure. Intensity of staining in the cell type toward which an antiserum was directed served as the endpoint for evaluation. Absence of immunostaining after preabsorption with the immunogen used in raising the antiserum indicated specificity, while absence of immunostaining with an antiserum absorbed with a different hormone indicated cross-reactivity and nonspecificity.
To this end an antiserum was absorbed in the following manner. After a hormone had been dissolved in physiological buffered saline, 10 $\mu l$ was incubated overnight at $4^{\circ} \mathrm{C}$ with $10 \mu \mathrm{l}$ of the antiserum previously diluted to a concentration twice that used for routine staining. This procedure provided a preabsorbed antiserum having the same dilution as a nonabsorbed antiserum used for routine staining.

The following hormones used for absorption of antisera were obtained from the sources indicated: National Pituitary Agency (NIAMDD), hGH (G4.HS1395); Rat Pituitary Hormone Distribution Program, NIAMDD (A. F. Parlow), rGH (AFP-329-B), rPrl (RP. 1), $\operatorname{rTSH}(\mathrm{A}-143-\mathrm{C}), \mathrm{rFSH}(\mathrm{FSH} \cdot \mathrm{B} 1), \mathrm{hTSH} \beta$ (N-870-B), hFSH $\beta$ (NSP6-C); Organon, Inc., $\beta^{1-24}$-corticotropin (\#26153); Sigma, Ine., hCG (Lot 102C-0360); Calbiochem., Inc., hTSH (Lot 420064), hFSH (Lot 389549). We thank NIAMDD for the hormones provided. 
The final concentrations of the absorbing hormones ranged from 0.5 to $1,000 \mathrm{ng} / \mu \mathrm{l}$. The ideal absorbents would have been hormones obtained from hypophyses of mice but, since they were not available, hormones obtained from the rat, man, or by synthesis were used. These explorations for evidence of cross-reactivity were hampered by low solubility of some of the glycoprotein hormones. Although in most cases each absorbing hormone was used at several concentrations, for simplicity in table 2, only the minimal amount that neutralized an antiserum, and/or the maximal amount that failed, are shown. Anti-hFSH $\beta$, and antisera to the thyroptropins and their $\beta$-subunits, were preabsorbed routinely with hCG at final concentrations ranging from 0.75 to $1.25 \mathrm{IU} / \mu \mathrm{l}$ in order to eliminate antibodies to $\mathrm{LH}$.

For the purpose of ascertaining whether more than one hormone occurred in the same cell, and to acquire additional evidence regarding specificity of the procedure, consecutive pituitary sections were immunostained for different hormones and the reactivity of identical cells compared in the two sections.

Finally, sections from a few glands were stained with differential chemical methods including the Adams and Swettenham ('58) performic acid-aldehyde fuchsin-light greenorange $\mathrm{G}$ procedure for differentiation of thyrotropes from gonadotropes, and the Dawson and Friedgood ('38) modified Heidenhain "azan" method (azocarmine-methyl blueorange G), as well as the Brookes ('68) carmoisine L-wool green S-orange G procedure for differentiation of somatotropes and mammotropes. As has been the experience of many other investigators, poor differentiation of cell types was obtained. Nevertheless, an attempt was made to correlate cells revealed by chemical staining with those demonstrated by the immunocytochemical method.

\section{RESULTS}

Consideration will be given first to cell types commonly classed as acidophils on the basis of their affinity for certain acid stains such as eosin, acid fuchsin and orange $G$.

\section{Somatotrope}

The somatotrope possessed several distinctive morphological features. It was spheroidal or ovoid (figs. 1,5 ) and the considerable density of its cytoplasm probably reflected a high concentration of secretory granules. Because of these structural features the somatotrope could of ten be identified in unstained sections. Although the cytoplasm appeared granular in immunostained preparations, secretory granules could not be differentiated from clumps of oxidized DAB. Some somatotropes stained with orange $G$ in the Adams and Swettenham method and with azocarmine, rather than orange $\mathrm{G}$ as expected, in the Dawson-Friedgood procedure.

Somatotropes constituted a large proportion of the parenchymal cell population and were distributed quite generally in the gland (figs. $1 a, b, c)$. However, in both sexes few somatotropes appeared dorsal to the dorsolateral extension of the hypophyseal cleft (fig. 1a) and they were scarce in the "sex zone" that constitutes the cephalomedian part of the pars distalis (fig. 1c).

Somatotropes differed in the sexes with respect to several characteristics. On an average they were larger in the male (figs. 5,6). They also constituted a greater percentage of the cell population in the male (fig. 1a) than in the female (fig. 2). Finally, when immunostained sections from males (fig. 1a) and females (fig. 2) were compared at low magnification, the intensity of staining appeared less in the female. This difference probably resulted from the smaller size and correspondingly lesser granulation of somatotropes in the female, as well as a lesser relative number.

Specificity of the immunocytochemical procedure for detection of growth hormone was shown by the following control observations. Immunostaining of the somatotropes did not occur if anti-hGH was replaced with normal rabbit serum or preabsorbed with human growth hormone at $5 \mathrm{ng} / \mu \mathrm{l}$, while a 100 - or 200 -fold greater concentration of rat prolactin, $\beta^{1-24}$-corticotropin, rat thyrotropin, rat FSH or hCG failed to affect the antiserum (table 2). Unexplained is a weak cross-reaction between anti-hGH and rGH.

\section{Mammotrope}

Mammotropes were polyhedral (figs. 7, 8) and from the perikaryon cytoplasmic processes extended between neighboring parenchymal cells toward the capillaries. Granules in the cytoplasm, some of which may have been secretory in nature, were of irregular shapes. The differential chemical staining methods (Dawson-Friedgood; Brookes) nei- 
ther revealed the mammotropes distinctly nor differentiated them clearly from somatotropes.

Mammotropes made up a high percentage of the parenchymal cells and were distributed generally in the gland (figs. 3a,b,c) except that they tended to be few in the ventral part of the cephalomedian "sex zone" (fig. 3c). Mammotropes were often arranged in clusters.

Sex-related differences were marked in the mammotropes. Mammotropes were fewer in the male (fig. 4) than in the female (fig. 3b). Furthermore, they were exceedingly small in the male (fig. 7), the cytoplasm of the cell body forming a narrow rim around the nucleus and being poorly granulated. Long, thin cytoplasmic processes of the mammotropes commonly encompassed other cell types, particularly the somatotropes. In contrast, although varying a great deal in size, many mammotropes in females (fig. 8) possessed voluminous cytoplasm. The intense cytoplasmic immunostaining of these cells seemed to be associated with the presence of secretory granules.

Mammotropes were immunostained with two antisera to rat prolactin, each of which was prepared in a different laboratory. In both cases preabsorption of the antiserum with 5 $\mathrm{ng} / \mu \mathrm{l}$ of rat prolactin prevented subsequent immunostaining of mammotropes. In contrast, 10 to 200 times this concentration of most other pituitary hormones failed to affect the utility of anti-rPrl for immunostaining of mammotropes in the mouse. Of greatest importance was the absence of any evidence of cross-reaction between anti-Prl and either somatotropin or corticotropin. Thus, specificity of the antisera to $\mathrm{rPr}$ for demonstration of mammotropes in the mouse seemed reasonably certain. Anti-hPrl was ineffective in the mouse and anti-oPrl was only minimally effective.

\section{Corticotrope}

When chemically stained preparations of the hypophysis from the rat or mouse are observed with light microscopy, the corticotrope is not recognizable. Hence, it would be classed as a chromophobe. However, in the rat it stains lightly with the periodic acid-Schiff reaction and intensely with aldehyde fuchsin (Baker et al., '70), probably because the intracellular prohormone of corticotropin is a glycoprotein (Eipper et al., '76). Since a glyco- protein product is present in the cell, it resembles a basophil.

In the mouse, corticotropes were small, stellate, and characterized by cytoplasmic processes that projected between neighboring cells (figs. 21, 24, 26). As compared with somatotropes and mammotropes they were few, and exhibited a much different distributional pattern. In the caudal (fig. 9a) and middle (fig. 9b) pituitary regions, corticotropes appeared most commonly near the ventral surface of the gland; in the medial region of the lateral wing they spread dorsally to form bilateral centromedial groups (fig. 9b). More cephalically (fig. 9c) these groups were joined by a bridge of corticotropes that extended across the median "sex zone." A few corticotropes were scattered peripherally inside the lateral and dorsal surfaces of the lateral wings. On the other hand, the centrolateral region (fig. $9 b)$ of the lateral wing and a broad zone under. lying the pars intermedia were almost totally devoid of corticotropes. No significant differences were observed between the sexes in size, number, or distribution of corticotropes.

Corticotropes were demonstrated with antisera to both $\beta^{1-24}$-corticotropin (fig. 9) and ${ }_{p} \beta^{17-39}$-corticotropin (fig. 10). Specificity was indicated by complete neutralization of the antisera by prior absorption with $\beta^{1-24}$-corticotropin at a concentration of $0.5 \mathrm{ng} / \mu \mathrm{l}$ (table 2). On the other hand, preabsorption of these antisera with 100- to 1,000-fold greater concentrations of the other hormones failed to negate the utility of the antisera for immunostaining of corticotropes.

The finding of corticotropin in most cells of the pars intermedia (figs. 9a,b, 10) was not unexpected since it has been demonstrated re. peatedly in the pars intermedia of the rat (Nakane, '70; Baker and Drummond, '72).

Following are descriptions of cells considered to be basophils and to secrete glycoprotein hormones.

\section{Thyrotrope}

Generally the thyrotrope was a large polyhedral cell, and its sides were commonly in. dented by adjacent somatotropes (fig. 27). It stained with aldehyde fuchsin as well as PAS. The distribution of thyrotropes in the pars dis. talis was somewhat distinctive, being restricted almost solely to the ventral one-half (figs. 11a,b,c). They occurred rarely in the ventromedial region of caudal sections (fig. 11a). 
No differences were observed between the sexes in size, number or distribution of thyrotropes (fig. 11b vs. fig. 12).

Thyrotropes were immunostained with anti-hTSH $\beta$ (fig. 11b), anti-bTSH $\beta$ (fig. 12), anti-bTSH and anti-hTSH, each of the antisera having been preabsorbed with hCG to remove contaminating antibodies to LH. Antisera to the $\beta$-subunits of bovine and human thyrotropin usually revealed more cells than antiserum to intact human thyrotropin and thus seemed more useful for immunostaining of the mouse pituitary gland.

Specificity of anti-hTSH $\beta$ was indicated by failure of the antiserum to permit immunostaining of thyrotropes in the mouse hypophysis after it was preabsorbed with human TSH and $\operatorname{TSH} \beta$ at $2.5 \mathrm{ng} / \mu \mathrm{l}$ (table 2). All of the other pituitary hormones tested for cross-reactivity with anti-hTSH $\beta$ had no influence on the antiserum at 200 times greater concentrations. Complete neutralization of anti-hTSH $\beta$ with rTSH was not obtained; this result we cannot explain. In general, examination of identical cells in consecutive sections, one of which was immunostained with anti-hTSH $\beta$ and the other with an antiserum to a different hormone or its $\beta$-subunit, supported the specificity of anti-hTSH $\beta$ for immunocytochemical staining of thyrotropes. Thus, different cells were revealed by anti-hCG (fig. 22) as compared with anti-hTSH $\beta$ (fig. 23), and by anti- $\beta^{1-24}$-corticotropin (fig. 26) as compared with anti-hTSH $\beta$ (fig. 27). On the other hand, although anti-hFSH $\beta$ (fig. 28) revealed many gonadotropes that remained untouched by anti-hTSH $\beta$ (fig. 29), at least occasional cells were immunostained by both antisera.

\section{Gonadotropes}

Gonadotropes, as demonstrated immunocytochemically, with anti-hCG (fig. 18) or anti-bLH $\beta$ (fig. 16), were most commonly polyhedral but some of the larger ones tended to be spheroidal. Gonadotropes were numerous and distributed throughout the gland (figs. $13 a, b, c)$; they formed a dense aggregation in the cephalic ventromedial "sex zone" (fig. 13c). Large gonadotropes occurred at the periphery of the pars distalis and along the hypophyseal cleft (fig. 16). Gonadotropes were larger, and possibly more numerous, in the male than in the female (fig. 16 vs. fig. $13 \mathrm{~b}$ ). They often contained cytoplasmic vacuoles, these being more common in males.
In addition to anti-hCG, gonadotropes were immunostained with anti-bLH $\beta$, anti-hLH $\beta$ and anti-rLH $\beta$. By comparison of consecutive sections stained with the different antisera, it was evident that identical cells were demonstrated with these antisera, as illustrated for anti-rLH $\beta$ (fig. 14) and anti-hLH $\beta$ (fig. 15).

Immunostaining with anti-hFSH $\beta$, after preabsorption with hCG to remove antibodies to $\mathrm{LH}$, revealed gonadotropes (fig. 17) that were of comparable number and distribution to those demonstrated with other antisera for LH, including anti-bLH $\beta$ (fig. 16). Furthermore, as shown by staining of consecutive sections, identical cells were brought out by antihCG (fig. 18) and anti-hFSH $\beta$ (fig. 19) preabsorbed with hCG.

With the procedure used, anti-hFSH $\beta$, preabsorbed with hCG, and anti-hCG seemed reasonably specific for labeling of FSH and $\mathrm{LH}$, respectively. Anti-hFSH $\beta$ was neutralized by $\mathrm{hFSH} \beta$ at $0.5 \mathrm{ng} / \mu \mathrm{l}$ while absorption with a 1,000-fold greater concentration of hCG had no effect on this antiserum (table 2). However, hFSH and rFSH were less effective than $\mathrm{hFSH} \beta$ in neutralizing anti-hFSH $\beta$. AntihCG was neutralized by $2.5 \mathrm{ng} / \mu \mathrm{l}$ of hCG but a similar effect was not obtained with a 200 -fold higher concentration of rFSH.

Anti-bLH $\beta$ seemed to be a desirable antiserum for demonstration of gonadotropes in the mouse. When used at high concentration both thyrotropes and gonadotropes were stained, but at dilutions of $1 / 1,000$ to $1 / 3,000$ only gonadotropes were revealed. Nevertheless, cross-reaction studies did not provide strong support for its specificity. Anti-bLH $\beta$ was neutralized by bLH at $5 \mathrm{ng} / \mu \mathrm{l}$ but failed to cross-react with hCG at $50 \mathrm{ng} / \mu \mathrm{l}$. Partial or complete neutralization appeared at higher concentrations of rFSH and rTSH but no cross-reactivity was demonstrated with $\mathrm{rGH}$, rPrl, or $\beta^{1-24}$-corticotropin.

The immunological relationship of antihFSH $\beta$ and anti-hCG to TSH merits special consideration. With respect to anti-hFSH $\beta$, rTSH at $500 \mathrm{ng} / \mu$ l exhibited slight cross-reactivity but hTSH completely neutralized it (table 2). Only partial neutralization resulted with hTSH at $50 \mathrm{ng} / \mu \mathrm{l}$ but this amount was still 100 times greater than the minimal amount of $\mathrm{hFSH} \beta$ required for complete elimination of effectiveness in anti-hFSH $\beta$. Thus, anti-hFSH $\beta$ should be satisfactory for differentiation of FSH from TSH. With anti- 
hCG there was evidence of cross-reactivity with hTSH, rTSH and hTSH $\beta$ within a range of 20 multiples in the concentrations of the $a b$ sorbents. With respect to both anti-hFSH $\beta$ and anti-hCG there was no evidence of significant cross-reactivity with corticotropin, somatotropin or mammotropin.

\section{DISCUSSION}

The following discussion attempts to evaluate the extent to which immunocytochemistry can facilitate investigation of pituitary cytology in the mouse and to correlate our immunocytochemical observations of secretory cell types with those reported by earlier investigators who employed chemical staining procedures or electron microscopy.

\section{Acidophils: somatotropes, mammotropes}

With the light microscope, somatotropes have been identified in several studies of the mouse by virtue of their affinity for acid dyes such as orange $\mathrm{G}$ and erythrosin. However, no one has reported success in differentiating somatotropes from mammotropes, or in identifying mammotropes with differential chemical staining, as has been accomplished in many other mammalian species. Indeed, Dev and Srivastava ('75) observed in the male mouse that the Cleveland-Wolfe erythrosinorange $\mathrm{G}$ procedure stained some dark ovoid to spheroidal cells with orange $G$ and others with erythrosin. They attributed secretion of prolactin to the orangeophils and growth hormone to erythrosinophils. However, it is evident from the structure of the cells they stained, and the evidence presented herein, that these workers observed only somatotropes and that mammotropes, which possess a markedly different morphology, were not detected.

Previous attempts to demonstrate somatotropes and mammotropes in the mouse with immunohistological methods have met with variable success. Weidner ('72) showed with anti-bGH that at least some acidophils contain growth hormone, but he failed to identify mammotropes with anti-bPrl. It is probable that Furth et al. ('73) successfully differentiated somatotropes and mammotropes with immunocytochemistry. However, uncertainty exists regarding their conclusions because so few details were given regarding the structure of the cells that were stained, and because control measures to demonstrate spe- cificity of the procedure and antisera were not carried out.

The failure of anti-hPrl to permit immunocytochemical staining of mammotropes in the mouse was not unexpected because a simi. lar result was obtained in the rat (Baker and $\mathrm{Yu}$, '77). Likewise, anti-oPrl was minimally effective in the rat. These observations are difficult to understand because both anti-rPrl and anti-oPrl are effective for demonstration of mammotropes in man (Halmi et al., '75; Baker and $\mathrm{Yu}$, '77).

With the electron microscope, greater certainty and uniformity of opinion seem to exist regarding criteria that may be used for identification of somatotropes and mammotropes in the mouse. All workers in this area (Barnes, '63; Yamada and Yamashita, '67; GomezDumm and Echave-Llanos, '72) have agreed that the somatotrope is ovoid to spheroidal, contains electron-opaque spheroidal secretory granules measuring $350-400 \mathrm{~nm}$ in diameter, and of all cell types in the gland may be of highest frequency. With respect to the mammotropes less attention has been given to shape of the cell but agreement exists regarding the pleomorphic shape of the secretory granules, and their width, which varies from about 200-400 nm or more (Sano, '62; Barnes, '63; Gomez-Dumm and Echave-Llanos, '72). As compared with the female, somatotropes of the male mouse are reported to be larger and more numerous, while mammotropes are smaller and somewhat fewer (Sasaki, '74). These latter conclusions conform to those drawn from our observations based on immunocytochemical observation of the two cell types. Also, the greater prominence of mam. motropes in the hypophysis of the female mouse, as compared with the male, parallels a higher prolactin content (Hurst and Turner, '42).

Thus it seems probable that somatotropes and mammotropes of the mouse hypophysis can be differentiated by means of either electron microscopy or immunocytochemistry. With respect to the latter procedure, this conclusion is based on specificity of the methods used, as well as striking morphological differences between the two cell types. Finally, except for granule size, the anatomical characteristics of these cell types resemble those of somatotropes and mammotropes in the rat, which have been studied extensively by both electron microscopy (Kurosumi, '68; Moriarty, 
'73; Farquhar et al., '75) and immunocytochemistry (Baker et al., '69; Baker, '74).

\section{Corticotropes}

The corticotrope of the mouse has never been described from tissue sections prepared with differential chemical staining. With electron microscopy only Yamada and Yamashita ('67) and Sasaki ('74) have attempted to locate the cell but much stronger evidence is needed to support the identifications that they made. Incidental to a study with immunofluorescence of corticotropes in the rostral zone of the mouse pars intermedia, Stoeckel et al. ('73a,b) illustrated corticotropes in the pars distalis but did not describe them. Hence, our description of the cytology and intraglan. dular distribution of corticotropes in the hypophyseal pars distalis of the mouse is the first to appear. Although the technique used for their demonstration appears to have been specific, additional studies are needed to show that the cell responds to alterations in the factors that control its activity.

\section{Basophils: thyrotropes, gonadotropes}

For two reasons, the establishment of immunocytochemical specificity in the staining of subclasses of basophils is difficult. Recent advances in understanding of the chemical structure of glycoprotein hormones indicate that each hormone consists of an $\alpha$ and a $\beta$ subunit. Within a species, the $\alpha$-subunit possesses a similar structure in LH, FSH, and TSH, while the $\beta$-subunit is structurally unique and accounts for the biological and specific immunological properties of the intact hormone (Pierce, '71; Vaitukaitis et al., '72). Because of the common $\alpha$-subunit, absence of specificity in immunocytochemical staining is always possible. Second, complete purification of LH, FSH, and TSH is difficult so that apparent cross-reactivity may be due to hormonal contamination of the antigen used for immunization, or of the hormone used for absorption in control procedures.

Due to the presence of the carbohydrate moiety in glycoprotein hormones, there may be similarities in the histochemical reactions exhibited by the cells that secrete them. Thus, all basophils are PAS-positive. Furthermore, the thyrotrope (Halmi, '52a,b) and corticotrope (Baker et al., '70) of the rat both stain with aldehyde fuchsin.

Because thyrotropes have the capacity to stain with aldehyde fuchsin they have been studied in the mouse by several investigators (Halmi and Gude, '54; Yamada et al., '57; Israel and Ellis, '61; Messier, '65; Dev and Srivastava, '75). All of these workers agree that the thyrotrope is polyhedral and that most thyrotropes are located "centrally" in the pars distalis. Our immunocytochemical observations are in accord with these conclusions. Indeed, the composite diagram of Messier ('65) illustrating the location of thyrotropes in the midportion of the hypophysis is borne out closely by our illustrations of thyrotropes immunostained with anti-TSH $\beta$ (figs. $11 \mathrm{~b}, 12$ ). In addition, figures $11 \mathrm{a}$ and $11 \mathrm{c}$ confirm Messier's conclusion, derived from differential cell counts in coronal sections, that the percentage of thyrotropes is less in the caudal and cephalic regions than in the middle region of the mouse hypophysis. On the other hand, our findings on immunostained tissue show that the conclusion of Israel and Ellis ('61) and of Dev and Srivastava ('75), that thyrotropes are absent at the periphery of the pars distalis, does not apply to the ventral region.

As pointed out previously, a few gonadotropes that immunostained with anti-FSH $\beta$ reacted also with anti-TSH $\beta$, indicating that FSH and TSH may exist in the same cell. For two reasons this is probably a valid conclusion. First, the control procedures provided little evidence of cross-reactivity between the antisera used for demonstrating FSH-gonadotropes and thyrotropes on the one hand and several preparations of FSH and TSH on the other. Second, the fact that only occasional cells stained for both FSH and TSH, while most did not, is a strong argument against cross-reaction having occurred. Thus, if during immunostaining, a cross-reaction had taken place between anti-hFSH $\beta$ and mouse TSH, or between anti-hTSH $\beta$ and mouse FSH, it should have been apparent in most of the FSH- or TSH-containing cells, which was not the case.

Surprisingly little attention has been given to gonadotropes in the mouse as observed with light microscopy. Dev and Srivastava ('75) subdivided gonadotropes, all of which stained with both PAS and aldehyde thionin, into two types, (a) large oval cells with fine granules, and (b) small round cells with coarse granules. They thought that the small round cells may be the source of LH. Our preparations indicate that a polyhedral shape must be emphasized as being rather typical of mouse gonadotropes - with the spheroidal form in the female 
being restricted almost solely to peripheral and cephalic regions of the gland. The poly. hedral shape was stressed also in electron microscope studies (Barnes, '63; GomezDumm and Echave-Llanos, '72). Spheroidal gonadotropes are more common in the male. The general distribution of gonadotropes in the pars distalis was impressive in our preparations and differs somewhat from the single other available description (Halmi and Gude, '54). Immunocytochemical observations show that gonadotropes are quite numerous and scattered diffusely throughout the pars distalis except for a prominent aggregation of cells in the cephalomedian region ("sex zone"). The larger size of gonadotropes in males than in females, as reported by Yamada et al. ('57) and Sasaki ('74), was confirmed by our preparations. Similarly supported was the discovery by Yamada et al. ('57) that vacuoles occur in the cytoplasm of gonadotropes and that they tend to be more common in males than females. Based on electron microscopic observations, Sasaki ('74) concluded that structural differences exist between the sexes in somatotropes, mammotropes, and gonadotropes; on the basis of immunocytochemical observations we concur.

There seems little doubt that LH was demonstrated within gonadotropes since antisera to four preparations of $\mathrm{LH}$ were used, three of these preparations being to the $\beta$-subunit obtained from different species. Insofar as could be ascertained, identical cells were revealed immunocytochemically by all antisera. Further, the evidence indicates that FSH is present also in most gonadotropes that contain LH. This conclusion agrees with that reported for gonadotropes of the rat (Nakane, '70; Herbert, '75), monkey (Herbert, '76), and man (Phifer et al., '73).

The polyhedral shape of gonadotropes points to the danger of confusing them with corticotropes or thyrotropes which are of similar form. In addition, the distributional pattern of gonadotropes overlaps the regions where the latter cell types are most common, namely, in the centromedian region of the lateral wing of the pars distalis. With respect to thyrotropes and corticotropes, their differentiation seems to have been accomplished with immunostaining because of the minimal evidence of cross-reactivity obtained (table 2 ) and the fact that different cells were revealed consistently by the antisera used. For similar reasons the FSH-gonadotrope and corticotrope seem to be different cells but caution is appropriate because Moriarty and Garner ('77) have reported that some cells in the rat hypophysis may contain both FSH and corticotropin. Since LH-gonadotropes are of greater number and more general intraglandular distribution in the mouse, it is quite evident that most of those revealed by any of the four antisera to LH or its subunits do not contain thyrotropin or corticotropin. This generalization is borne out by the minimal evidence of cross-reactivity with the latter hormones and our inability to find cells that would stain with both anti-hCG and anti- $\beta^{i-24}$ - corticotropin or anti-hTSH $\beta$. Remaining a problem for future immunocytochemical study of the mouse hypophysis is the possibility that TSH and FSH exist together in some cells. Since most gonadotropes appear to contain both $\mathrm{LH}$ and FSH, the reason why we did not find $\mathrm{LH}$ and TSH together in gonadotropes is not evident. Additional search might have revealed such cells; if present their number must be exceedingly small.

In conclusion, the five secretory cell types generally recognized in the hypophyseal pars distalis can be identified readily with immunocytochemistry in the mouse. It follows that immunocytochemistry is a promising method for study of the pituitary gland in numerous areas of biomedical research when the mouse serves as the subject animal.

\section{LITERATURE CITED}

Adams, C. W. M., and K. V. Swettenham 1958 The histochemical identification of two types of basophil cell in the normal adenohypophysis. J. Path. and Bact., 75: 95-103.

Baker, B. L. 1974 Functional cytology of the hypophysial pars distalis and pars intermedia. In: The Pituitary Gland and Its Control-Adenohypophysis. Handbook of Physiology, Endocrinology IV, Part 1. R. O. Greep and E. Knobil, eds. Amer. Physiol, Soc., Bethesda, pp. 45-79.

Baker, B. L., and T. Drummond 1972 The cellular origins of corticotropin and melanotropin as revealed by immunochemical staining. Am. J. Anat., 134: 395-410.

Baker, B. L., F. J. Karsch, D. L. Hoffman and W. C. Beckman, Jr. 1977 The presence of gonadotropic and thyrotropic cells in the pituitary pars tuberalis of the monkey (Macaca mulatta). Biol. Reprod., 17: 232-240.

Baker, B. L., A. R. Midgley, Jr., B. E. Gersten and Y.-Y. Yu 1969 Differentiation of growth hormone and prolactin. containing acidophils with peroxidase-labeled antibody. Anat. Rec., 164: 163-171.

Baker, B. L., S. Pek, A. R. Midgley, Jr., and B. E. Gersten 1970 Identification of the corticotropin cell in rat hypophyses with peroxidase-labeled antibody. Anat. Rec. 166: 557-563.

Baker, B. L., and Y.-Y. Yu 1977 An immunocytochemical study of human pituitary mammotropes from fetal life to old age. Am. J. Anat., 148: 217-239.

Barnes, B. G. 1963 The fine structure of the mouse adenohypophysis in various physiological states. In: $\mathrm{Cy}$ - 
tologie de l'Adenohypophyse. Editions du Centre National de la Recherche Scientifique, Paris, pp. 91-110.

Brookes, L. D. 1968 A stain for differentiating two types of acidophil cells in the rat pituitary. Stain Tech., 43: $41-42$.

Dawson, A. B., and H. B. Friedgood 1938 Differentiation of two classes of acidophils in the anterior pituitary of the female rabbit and cat. Stain Tech., 13: 17-21.

Dev, P. K., and P. N. Srivastava 1975 Tinctorial behavior of the cell types in the adenohypophysis of Swiss albino mice. Acta Anat., 92: 178-193.

Eipper, B. A., R. E. Mains and D. Guenze 1976 High molecular weight forms of adrenocorticotropic hormone are glycoproteins. J. Biol. Chem., 251: 4121-4126.

Farquhar, M. G., E. H. Skutelsky and C. R. Hopkins 1975 Structure and function of the anterior pituitary and dis. persed pituitary cells. In vitro studies. In: The Anterior Pituitary. A. Tixier-Vidal and M. G. Farquhar, eds. Academic Press, New York, pp. 83-135.

Furth, J., P. Moy, D. L. Schalch and G. Ueda 1973 Gonadotropic activities of thyrotropic tumors; demonstration by immunohistochemical staining. Proc. Soc. Exp. Biol. Med., 142: 1180-1184.

Gomez-Dumm, C. L. A., and J. M. Echave-Llanos 1972 Further studies on the ultrastructure of the pars distalis of the male mouse hypophysis. Acta Anat., 82: 254-266.

Halmi, N. S. 1952a Two types of basophils in the rat pituitary: "thyrotrophs" and "gonadotrophs" vs beta and delta cells. Endocrinology, 50: 140-142.

$1952 \mathrm{~b}$ Differentiation of two types of basophils in the adenohypophysis of the rat and the mouse. Stain Tech., 27: 61-64.

Halmi, N. S., and W. D. Gude 1954 The morphogenesis of pituitary tumors induced by radiothyroidectomy in the mouse and the effects of their transplantation on the pituitary body of the host. Am. J. Path., 30: 403-411.

Halmi, N. S., J. A. Parsons, S. R. Erlandsen and T. Duello 1975 Prolactin and growth hormone cells in the human hypophysis: a study with immunoenzyme histochemistry and differential staining. Cell Tiss. Res., 158: 497-507.

Herbert, D. C. 1975 Localization of antisera to LH $\beta$ and FSH $\beta$ in the rat pituitary gland. Am. J. Anat., 114: 379-385.

1976 Immunocytochemical evidence that LH and FSH are present in the same cell type in the rhesus monkey pituitary gland. Endocrinology, 98: 1554-1557.

Hurst, V., and C. W. Turner 1942 Lactogenic hormone content of anterior pituitary gland of albino mouse as compared to other species. Endocrinology, 31: 334-339.

Israel, M. S., and R. Ellis 1961 The pituitary changes in mice undergoing thryoid hyperplasia. Brit. J. Cancer, 15: 763-768.

Kurosumi, K. 1968 Functional classification of cell types of the anterior pituitary gland accomplished by electron microscopy. Arch. Histol. Jap., 29: 329-362.
Messier, B. 1965 Number and distribution of thyrotropic cells in the mouse pituitary gland. Anat. Rec., 153: 343-348.

Moriarty, G. C. 1973 Adenohypophysis: ultrastructural cytochemistry. A review. J. Histochem. Cytochem., 21: 885-894.

Moriarty, G. C., and L. L. Garner 1977 Immunocytochemical studies of cells in the rat adenohypophysis containing both ACTH and FSH. Nature, 265: 356-358.

Nakane, P. K. 1970 Classifications of anterior pituitary cell types with immunoenzyme histochemistry. J. Histochem. Cytochem., 18: 9-20.

Phifer, R. F., A. R. Midgley and S. S. Spicer 1973 Immunologic and histologic evidence that follicle-stimulating hormone and luteinizing hormone are present in the same cell type in the human hypophysis. J. Clin. Endocr. Metab., 36: 125-141.

Pierce, J. G. 1971 Eli Lilly Lecture: The subunits of pituitary thyrotropin - their relationship to other glycoprotein hormones. Endocrinology, 89: 1331-1334.

Sano, M. 1962 Further studies on the theta cell of the mouse anterior pituitary as revealed by electron microscopy, with special reference to the mode of secretion. J. Cell Biol., 15: 85-97.

Sasaki, F. 1974 Quantitative studies by electron microscopy on the sex-difference and the change during the oestrous cycle in the mouse anterior pituitary. Arch. Histol. Jap., 37: 11-57.

Sternberger, L. 1974 Immunocytochemistry. PrenticeHall, Inc., Englewood Cliffs, N. J., pp. 143-144.

Stoeckel, M. E., H. D. Dellmann, A. Porte, M. J. Klein and F. Stutinsky 1973a Corticotrophic cells in the rostral zone of the pars intermedia and in the adjacent neurohypophysis of the rat and mouse. Z. Zellforsch., 136: 97-110.

Stoeckel, M. E., J. Doerr-Schott, A. Porte, H. D. Dellmann and M. P. Dubois 1973b Immunohistochemical demonstration of corticotrophic cells concentrated in the rostral zone of the pars intermedia of the mouse hypophysis. Experientia, 29: 1289-1290.

Vaitukaitis, J. L., G. T. Ross, L. E. Reichert, Jr. and D. N. Ward 1972 Immunologic basis for within and between species cross-reactivity of Iuteinizing hormone. Endocrinology, 91: 1337-1342.

Weidner, W. 1972 Immunohistologische Untersuchungen zur Lokalisation von STH and LTH im Hypophysenvorderlappen verschiedener Spezies. Beitr. Pathol., 145: 168-203.

Yamada, K., M. Sano and T. Ito 1957 A postnatal histogenetic study of the anterior pituitary of the mouse. Okajimas Folia Anat. Jap., 30: 177-195.

Yamada, K., and K. Yamashita 1967 An electron microscopic study on the possible site of production of ACTH in the anterior pituitary of mice. Z. Zellforsch., $80: 29-43$. 
PLATES 


\section{Abbreviations}
D, pars distalis
s, somatotrope
HC, hypophyseal cleft
m, mammotrope
$\mathrm{I}$, pars intermedia
c, corticotrope
$N$, pars nervosa
$t$, thyrotrope
$Z$, sex zone
$\mathrm{g}$, gonadotrope

PLATE 1

EXPLANATION OF FIGURES

All figures on this plate illustrate mouse hypophyses which were sectioned in a frontal plane; the ventral surface of the hypophysis is on the right and dorsal surface on the left. For figures 1 and 3 , the $a, b$ and $c$ photographs are from the caudal, middle, and rostral regions, respectively. Figures 2 and 4 are from the caudal and middle regions, respectively. Three micrometers. $\times 50$.

1 Male. Immunostained for somatotropes with anti-hGH. Somatotropes are sparse dorsal to the hypophyseal cleft $(a, b)$ and in the "sex zone" on the right (c).

2 Female. Immunostained for somatotropes with anti-hGH. As compared with the male (fig. 1a), somatotropes are fewer and appear more lightly stained.

3 Female. Immunostained for mammotropes with anti-rPrl (Parlow). Mammotropes are fewest in the cephalic section (c), especially in the "sex zone."

4 Male. Immunostained for mammotropes, which are few compared with the number in a comparable section from the female (fig. 3b). 

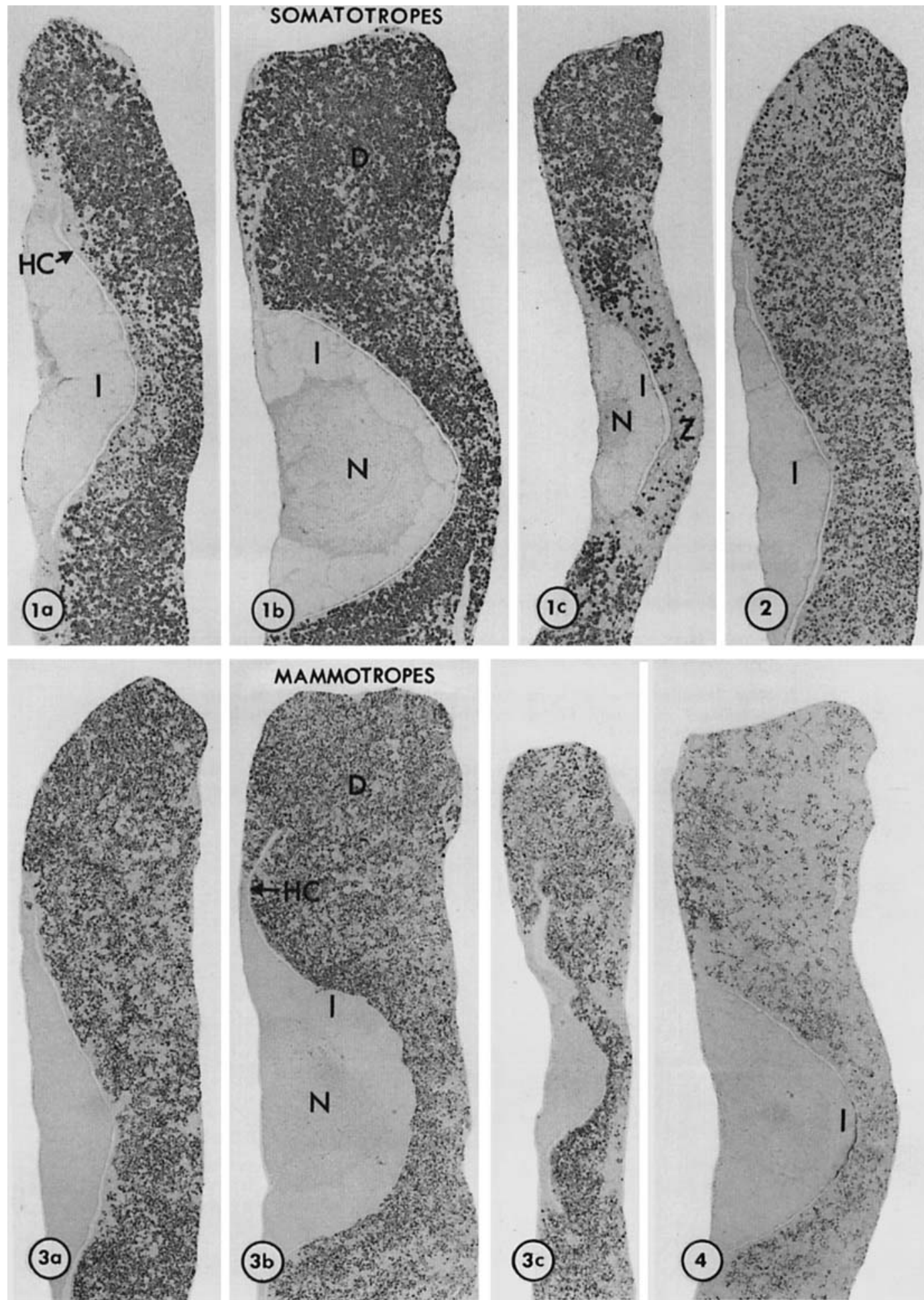


\section{PLATE 2}

\section{EXPLANATION OF FIGURES}

All illustrations on this plate are of photographs made in the lateral wing of the hypophyseal pars distalis. Three micrometers. $\times 1,000$.

5 Male. Immunostained for somatotropes with anti-hGH.

6 Female. Immunostained for somatotropes with anti-hGH. As compared with the male (fig. 5) somatotropes are smaller and fewer relative to the other cell types.

7 Male. Immunostained for mammotropes with anti-rPrl (Parlow). Mammotropes are exceedingly small with narrow cytoplasmic processes that partially encompass somatotropes (arrows).

8 Female. Immunostained for mammotropes with anti-rPrl (Parlow). Many mam. motropes are larger than in the male (fig. 7) and appear to contain large secretory granules. 

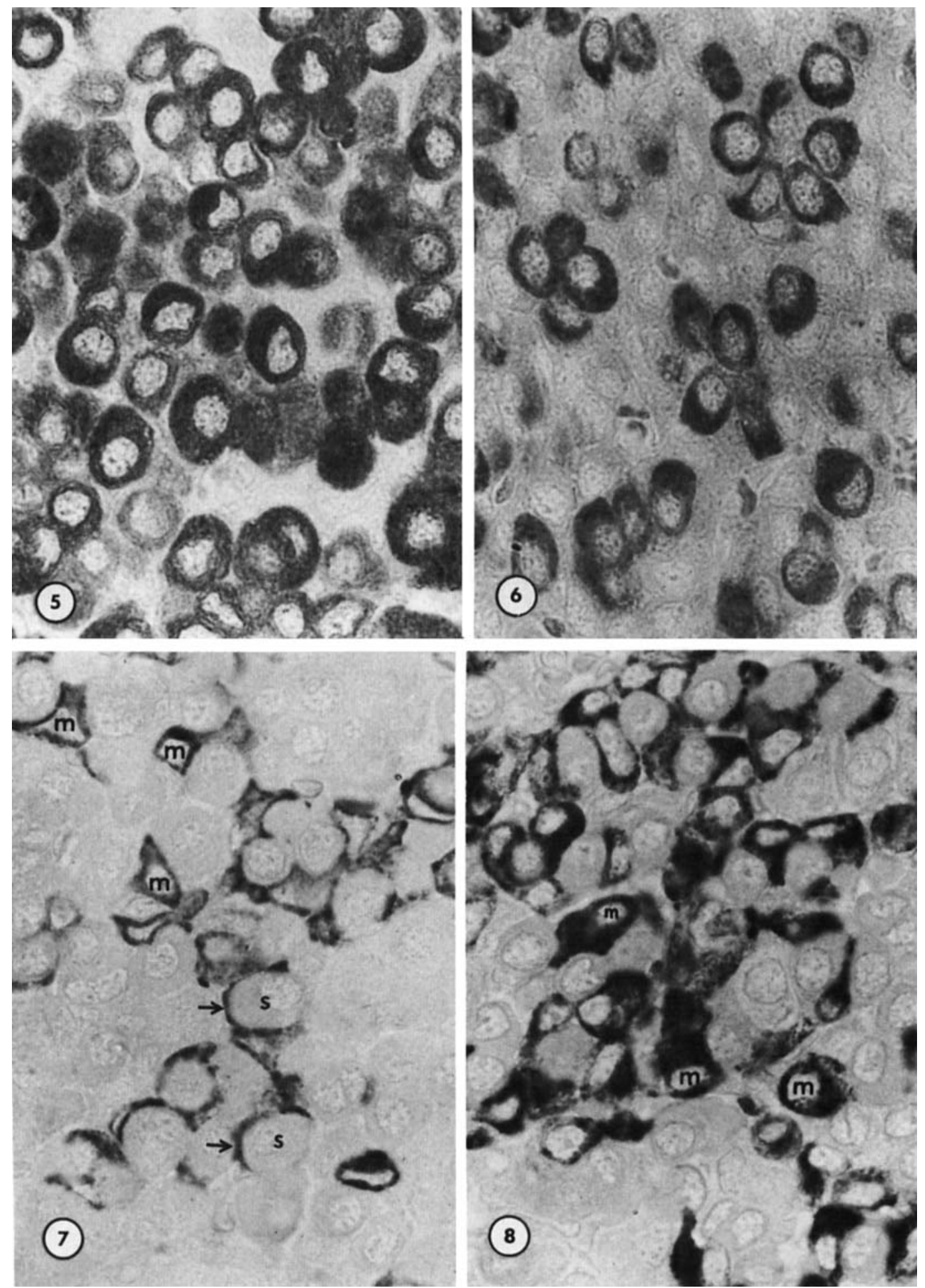
PLATE 3

EXPLANATION OF FIGURES

All figures on this plate illustrate mouse hypophyses which were sectioned in a frontal plane; the ventral surface of the hypophysis is on the right and the dorsal surface on the left. For figures 9 and 11 , the $a, b$, and $c$ photographs are from the caudal, middle, and rostral regions, respectively. Figures 10 and 12 are from the middle region. Three micrometers. $\times 50$.

9 Female. Immunostained for corticotropes with anti- $\beta^{1-24}$-corticotropin. Corticotropes are most common along the ventral border of the pars distalis $(a, b)$ and in the centromedian region of the lateral wing (b, $c$ ). The pars intermedia is stained.

10 Female. This section was obtained from the hypophysis illustrated in figure 9 and was near the section shown in figure $9 \mathrm{~b}$. Immunostained with anti-p $\beta^{17-39}$-corticotropin. The corticotropes are distributed similarly to those in figure $9 \mathrm{~b}$ stained with anti- $\beta^{1-24}$-corticotropin.

11 Female. Immunostained for thyrotropes with anti-hTSH $\beta$ preabsorbed with hCG. Thyrotropes are located predominantly in the ventral half of the pars distalis and are most numerous in the ventral portion of the central zone of the lateral wing.

12 Female. This section was obtained close to that shown in figure $11 \mathrm{~b}$; immunostained with anti-bTSH $\beta$, preabsorbed with hCG. The distribution of thyrotropes is similar to that revealed by anti-hTSH $\beta$ (fig. 11b). 
IMMUNOCYTOCHEMISTRY OF MOUSE HYPOPHYSIS

Burton L. Baker and Douglas S. Gross
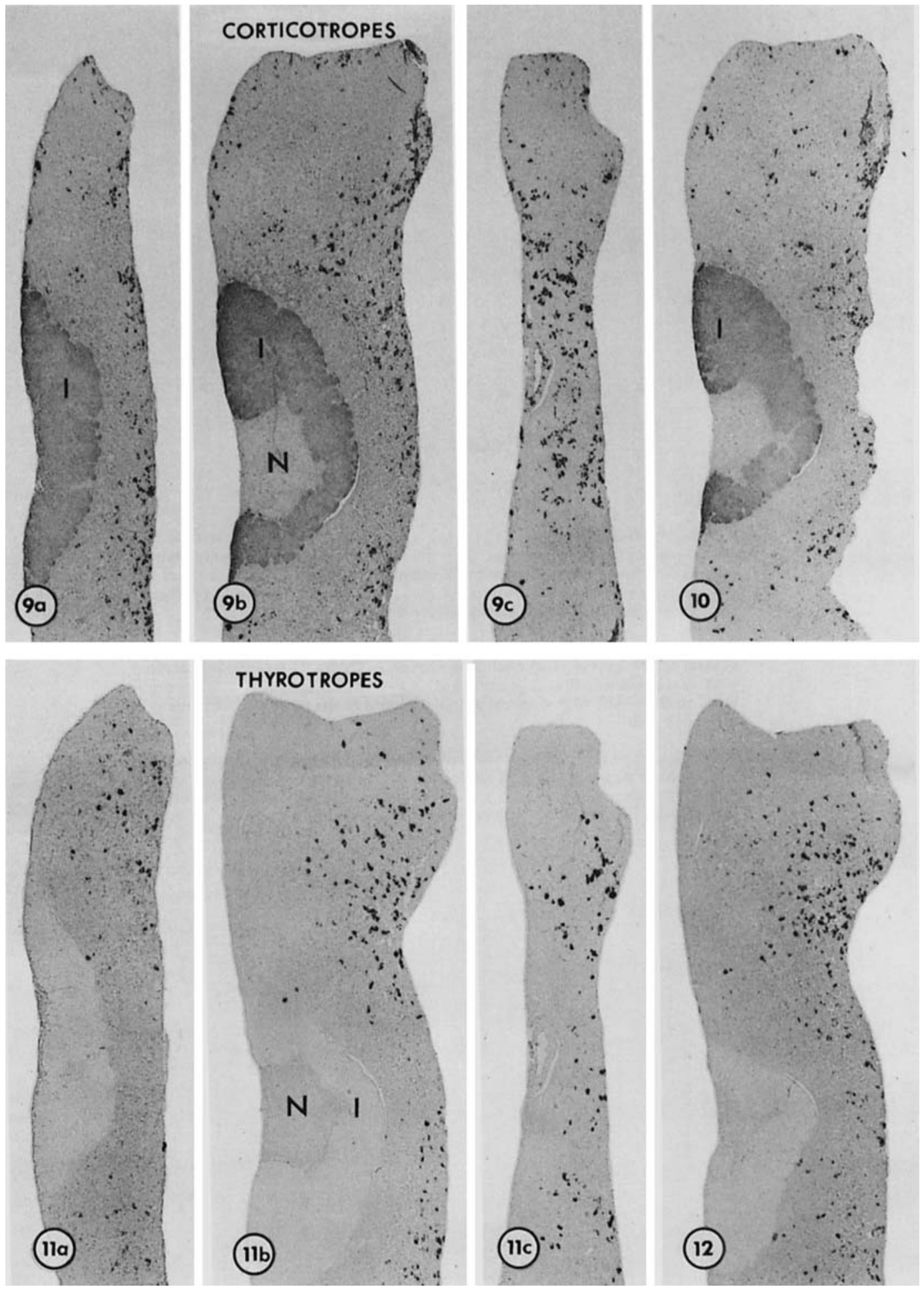
PLATE 4

EXPLANATION OF FIGURES

13 Female. Figures 13a, b, and c illustrate sections from the caudal, middle, and rostral regions of the hypophysis. They were cut in a frontal plane and immunostained for gonadotropes with anti-hCG. Gonadotropes are distributed generally and are most numerous rostrally (c) in the medial sex zone, as well as dorsal to the hypophyseal cleft. Three micrometers. $\times 50$.

14, 15 Female. These are adjacent sections from the lateral wing of the pars distalis ventral to the hypophyseal cleft. The section in figure 14 was immunostained with anti-rLH $\beta$ and that in figure 15 with anti-hLH $\beta$. Identical cells are num. bered to show that both antisera permit staining of the same cell. Three micrometers. $\times 440$.

16, 17 Male. Neighboring horizontal sections of one hypophysis are illustrated, the one shown in figure 16 having been immunostained with anti-bLH $\beta$ and that in figure 17 with anti-hFSH $\beta$, to show the similar distribution of gonadotropes that contain LH and FSH. Three micrometers, $\times 50$. 
Burton L. Baker and Douglas S. Gross
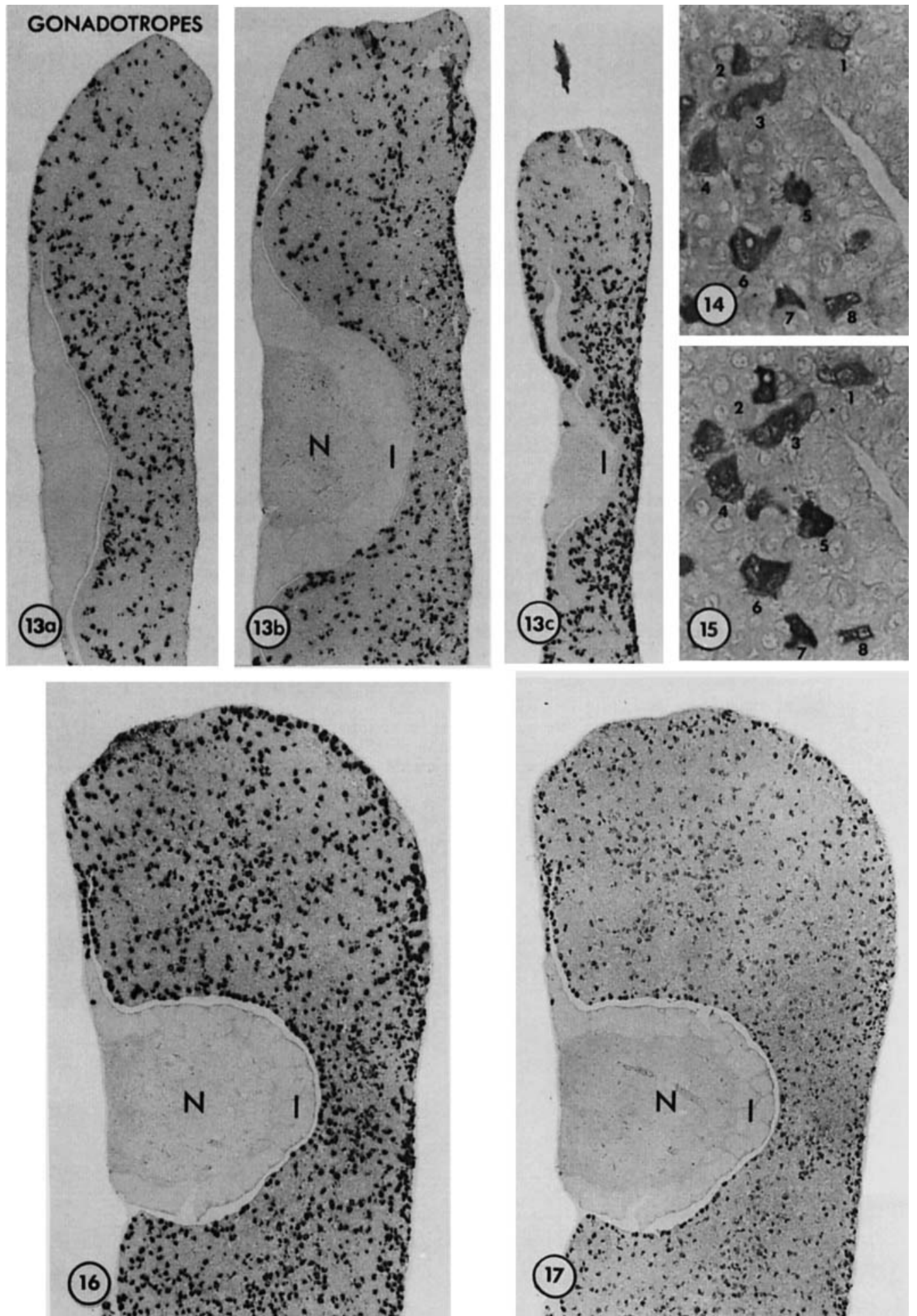


\title{
PLATE 5
}

\author{
EXPLANATION OF FIGURES
}

Figures 18, 20, and 22 represent sections that are consecutive to those shown in figures 19, 21, and 23, respectively. Each member of a pair was immunostained for a different cell type to secure evidence as to whether two hormones might occur in a single cell and/or the two antisera used might be specific for a single cell type. Immunostained cells, or groups of such cells, are numbered to facilitate their identifica. tion in the paired photographs. Five micrometers. $\times 440$.

18, 19 Male. Immunostained for gonadotropes with anti-hCG in figure 18 and with anti-hFSH $\beta$ in figure 19. All of the numbered cells are represented in both sections, indicating that $\mathrm{LH}$ and FSH occur in the same cells.

20,21 Male. Immunostained with anti-hCG for gonadotropes in figure 20 and with anti- $\beta^{1-24}$ corticotropin for corticotropes in figure 21 . The numbered gonadotropes stained in figure 20 are unstained in figure 21 , and the numbered corticotropes stained in figure 21 are unstained in figure 20.

22, 23 Female. Immunostained with anti-hCG for gonadotropes in figure 22, and with anti-TSH $\beta$ for thyrotropes in figure 20 . The numbered gonadotropes in figure 22 are unstained in figure 23 , and the numbered thyrotropes in figure 23 are unstained in figure 22 . 


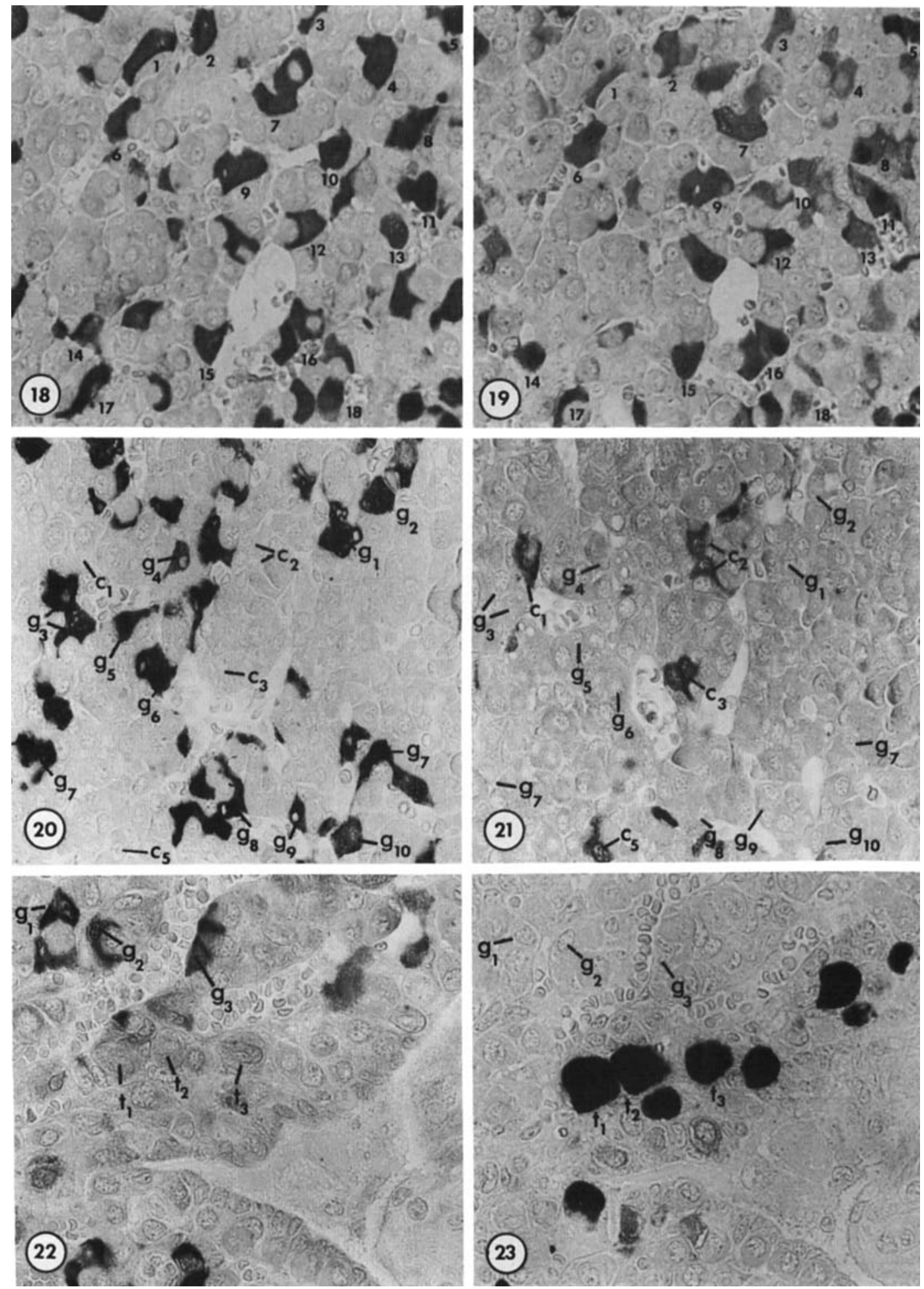




\section{PLATE 6}

EXPLANATION OF FIGURES

Figures 24, 26, and 28 represent sections that are consecutive to those shown in figures 25,27 , and 29 , respectively. Each member of a pair was immunostained for a different cell type. Five micrometers. $\times \mathbf{4 4 0}$.

24, 25 Male. Immunostained with anti- $\beta^{1-24}$-corticotropin for corticotropes in figure 24 , and with anti-hFSH $\beta$ for FSH-gonadotropes in figure 25 . The numbered corticotropes in figure 24 are unstained in figure 25 , and the numbered gonadotropes in figure 25 are unstained in figure 24 .

26, 27 Male. Immunostained with anti- $\beta^{1-24}$ corticotropin for corticotropes in figure 26 , and with anti-hTSH $\beta$ for thyrotropes in figure 27 . The numbered corticotropes stained in figure 26 are unstained in figure 27 , and the numbered thyrotropes stained in figure 27 are unstained in figure 26.

28, 29 Male. Immunostained with anti-hFSH $\beta$ for FSH-gonadotropes in figure 28 , and with anti-hTSH $\beta$ for thyrotropes in figure 29. Some of the gonadotropes (g) of figure 28 seem to correspond to thyrotropes ( $t$ ) in figure 29. Numerous gonadotropes of figure 28 are not stained in figure 29. 


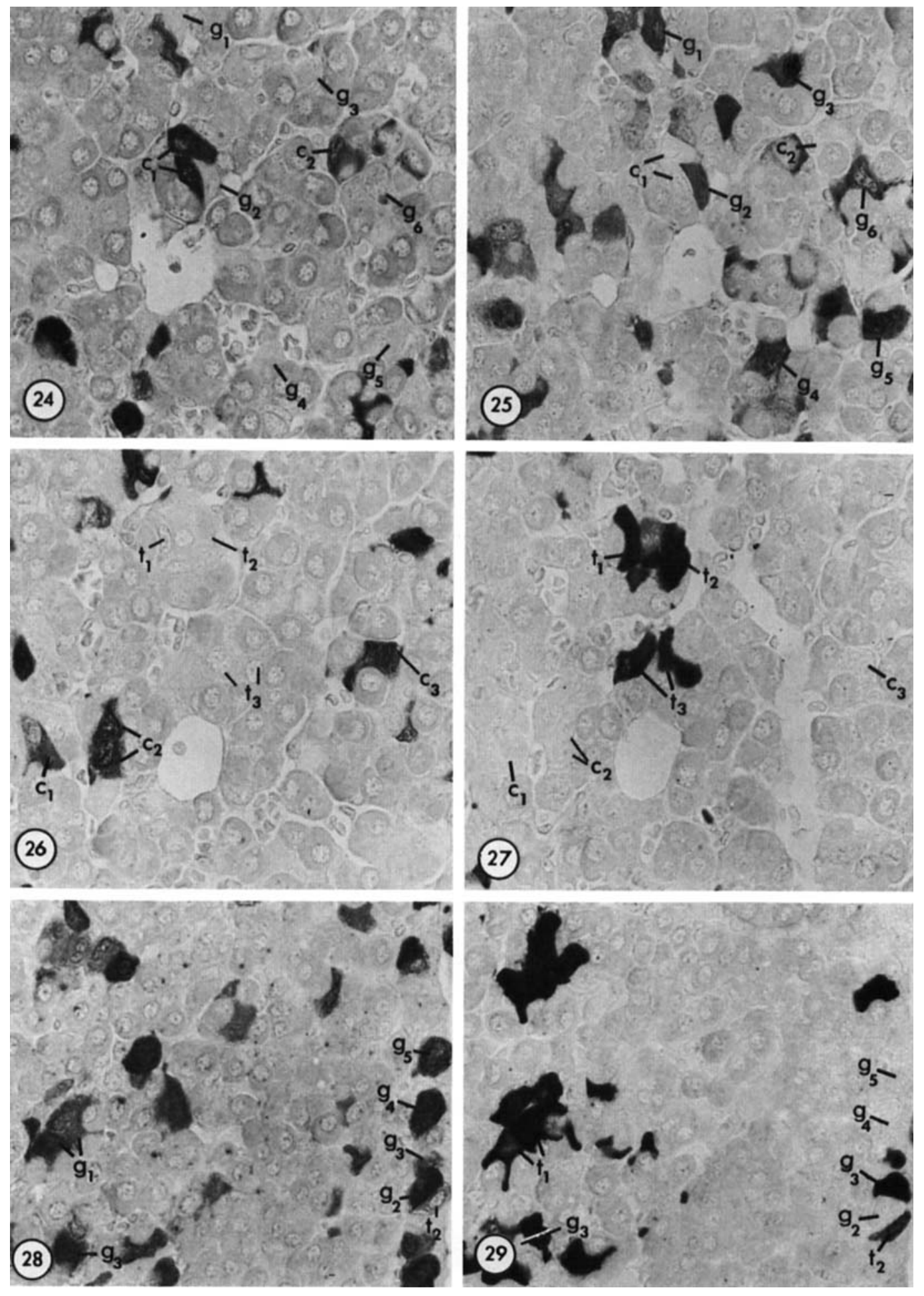

